\title{
《20 世纪中国知名科学家学术成就概览》简介
}

国家重点图书出版规划项目、国家出版基金资助项目《20 世纪中国知名科学家学术成就概览》 (简称《概览》) 受到党和政 府的高度重视和大力支持, 由著名科学家钱伟长院士倡议并任总 主编, 科学出版社组织出版. 这是一项重要的科学文化出版工程, 对于团结海内外华人科学技术、人文社会科学专家学者, 增强中 华民族的凝聚力和向心力, 对于传播科学、创造未来, 具有重大 政治意义和时代意义. 总主编钱伟长院士倡议, 以《概览》为载 体，“一是总结祖国过去的科学技术成就与贡献; 二是团结海内外 华人学者, 凝聚爱国精神; 三是教育和激发年轻一代为振兴中华 而奋发有为."

全书按学科分别结集卷册, 预计 19 卷 62 分册 3500 余万字, 包括地学、数学、农学、化学、生物学、医学、天文学、物理学、 力学、能源与矿业工程、土木水利与建筑工程、环境与轻纺工程、 化工冶金与材料工程、信息科学与技术、管理学以及经济学、哲
学、法学、考古学等卷(表 1). 书中以纪传文体记述约 3000 位知 名专家学者的求学经历和学术成就, 彰显他们为促进中国和世界 科技发展、经济和社会进步做出的贡献，秉承他们坚韧不拔的科 学精神和百折不挠的爱国传统, 力图对学界同行的学术探索有所 镜鉴, 对青年学生的学术成长有所启迪.

为与传文相映照, 并勾勒出中国各学术专业领域的百年发展 脉络, 各卷卷首先简要回顾学科发展简史, 卷末再另附学科发展 大事记, 进而在世界科学发展的大背景中, 标清中国各主要学科 研究的涨落、所处的位置和作用, 高度概括出各时期的代表人物、 重大事件、主要成果等.

《概览》图书编研出版项目得到中国科学院、中国工程院、 中国社会科学院、国家自然科学基金委员会等顶尖学术机构和重 要管理部门的众多知名院士和专家的学术支持和积极参与, 力求 材料的真实性、准确性和权威性.

表 1 《20 世纪中国知名科学家学术成就概览》丛书信息

\begin{tabular}{|c|c|c|c|c|c|c|c|c|c|}
\hline 主编 & 卷 & 分册 & 出版年 & 定价(元) & 主编 & 卷 & 分册 & 出版年 & 定价(元) \\
\hline \multirow[t]{6}{*}{ 孙鸿烈 } & 地学卷 & 地理学分册 & 2010 & 108 & \multirow{8}{*}{ 杜祥琬 } & & 第三分册 & 2014 & 218 \\
\hline & & 地球物理学分册 & 2010 & 78 & & 能源与矿业 & 矿业科学技术与工程分册 & 2013 & 148 \\
\hline & & $\begin{array}{l}\text { 大气科学与 } \\
\text { 海洋科学分册 }\end{array}$ & 2011 & 98 & & 工程卷 & $\begin{array}{l}\text { 动力与电气科学技术与 } \\
\text { 工程分册(一) }\end{array}$ & 2013 & 138 \\
\hline & & 地质学分册(一) & 2013 & 198 & & & 动力与电气科学技术与 & 2014 & 148 \\
\hline & & 地质学分册(二) & 2013 & 208 & & & 工程分册(二) & & \\
\hline & & 古生物学分册 & 2014 & 148 & & & 核科学技术与工程分册 & 2014 & 168 \\
\hline \multirow[t]{4}{*}{ 王元 } & 数学卷 & 第一分册 & 2011 & 76 & & & 地质资源科学技术与 & 2014 & 158 \\
\hline & & 第二分册 & 2011 & 68 & & & 工程分册 & & \\
\hline & & 第三分册 & 2012 & 110 & \multirow[t]{2}{*}{ 周干峙 } & 土木水利与建筑 & 第一分册 & 2014 & 188 \\
\hline & & 第四分册 & 2012 & 108 & & 工程卷 & 第二分册 & 2014 & 188 \\
\hline \multirow[t]{4}{*}{ 石元春 } & 农学卷 & 第一分册 & 2011 & 108 & \multirow[t]{2}{*}{ 魏复盛 } & 环境与轻纺 & 第一分册 & 2014 & 199 \\
\hline & & 第二分册 & 2012 & 138 & & 工程卷 & 第二分册 & 2014 & 168 \\
\hline & & 第三分册 & 2013 & 157 & \multirow[t]{4}{*}{ 干勇 } & 化工冶金与材料 & 冶金工程与技术分册(一) & 2014 & 115 \\
\hline & & 第四分册 & 2013 & 178 & & 工程卷 & 冶金工程与技术分册(二) & 2014 & 105 \\
\hline \multirow[t]{4}{*}{ 白春礼 } & 化学卷 & 第一分册 & 2011 & 98 & & & 化学工程与技术分册 & 2014 & 158 \\
\hline & & 第二分册 & 2012 & 148 & & & 材料科学与技术分册 & 2014 & 198 \\
\hline & & 第三分册 & 2013 & 138 & \multirow[t]{3}{*}{ 金国藩 } & 信息科学与 & 第一分册 & 2014 & 158 \\
\hline & & 第四分册 & 2014 & 158 & & 技术卷 & 第二分册 & 2014 & 148 \\
\hline \multirow[t]{3}{*}{ 梁栋材 } & 生物学卷 & 第一分册 & 2012 & 98 & & & 第三分册 & 2014 & 150 \\
\hline & & 第二分册 & 2013 & 128 & \multirow[t]{2}{*}{ 王礼恒 } & \multirow[t]{2}{*}{ 管理学卷 } & 第一分册 & 2013 & 149 \\
\hline & & 第三分册 & 2013 & 138 & & & 第二分册 & 2013 & 138 \\
\hline \multirow[t]{4}{*}{ 刘德培 } & 医学卷 & 中医与中西医结合分册 & 2013 & 138 & \multirow{6}{*}{$\begin{array}{l}\text { 张卓元 } \\
\text { 厉以宁 } \\
\text { 吴敬琏 } \\
\text { 汝信 }\end{array}$} & \multirow[t]{3}{*}{ 经济学卷 } & 第一分册 & 2013 & 178 \\
\hline & & 药学分册 & 2014 & 158 & & & 第二分册 & 2014 & 188 \\
\hline & & 基础医学与预防医学分册 & 2014 & 168 & & & 第三分册 & 2015 & 188 \\
\hline & & 临床医学与护理学分册 & 2015 & 218 & & \multirow[t]{3}{*}{ 哲学卷 } & 第一分册 & 2014 & 198 \\
\hline \multirow[t]{2}{*}{ 叶叔华 } & 天文学卷 & 第一分册 & 2014 & 175 & & & 第二分册 & 2014 & 208 \\
\hline & & 第二分册 & 2014 & 188 & & & 第三分册 & 2014 & 229 \\
\hline \multirow[t]{3}{*}{ 陈佳洱 } & 物理学卷 & 第一分册 & 2014 & 198 & \multirow[t]{3}{*}{ 江平 } & \multirow[t]{3}{*}{ 法学卷 } & 第一分册 & 2014 & 210 \\
\hline & & 第二分册 & 2014 & 208 & & & 第二分册 & 2014 & 198 \\
\hline & & 第三分册 & 2014 & 188 & & & 第三分册 & 2014 & 218 \\
\hline \multirow[t]{2}{*}{ 郑哲敏 } & 力学卷 & 第一分册 & 2014 & 199 & \multirow[t]{2}{*}{ 王巍 } & \multirow[t]{2}{*}{ 考古学卷 } & 第一分册 & 2014 & 170 \\
\hline & & 第二分册 & 2014 & 210 & & & 第二分册 & 2014 & 188 \\
\hline
\end{tabular}

快捷购书: 科学出版社直销部电话 010-64030226, E-mail: luwen@mail.sciencep.com; 科学出版社天猫旗舰店(http://kxcbs.tmall.com/); 定价以最终产品实际标称为准 